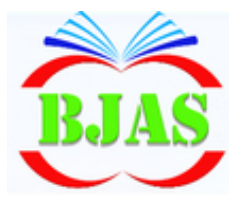

Available online at http://bajas.edu.iq

https://doi.org/10.37077/25200860.2019.254

College of Agriculture, University of Basrah

Basrah Journal

of Agricultural

Sciences

ISSN $1814-5868$

Basrah J. Agric. Sci. 32(Spec. Issue 2): 25-34, 2019

E-ISSN: 2520-0860

\title{
Response of Three Varieties of Cowpea( Vigna sinensis L.) to Different levels of potassium fertilizer under southern region conditions of Iraq
}

\author{
Ali K. Al-Furtuse ${ }^{1}$, Kifah A. Aldoghachi ${ }^{2} \&$ Waleed A. Jabail $^{3}$ \\ ${ }^{1}$ Agricultural Directorate of Maysan, Ministry of Agriculture, Iraq \\ ${ }^{2}$ Department of Field Crop, College of Agriculture, University of Basrah, Iraq \\ ${ }^{3}$ Department of Life Science, College of Education-Alqurna, University of Basrah, Iraq
}

*Corresponding author e-mail: ali22288090@gmail.com

Received 19 September 2019; Accepted 18 November 2019; Available online 22 November 2019

\begin{abstract}
A field experiment was conducted during autumn season 2018 at Al Salam district, Maysan governorate. The aim was to evaluate some growth properties and grain yield of three varieties of cowpea, Vigna sinensis L. (Local, Patton Boa and Atta E) grown under different levels of potassium sulphate $\left(0,43,86\right.$ and $\left.129 \mathrm{~kg} \mathrm{~h}^{-1}\right)$. The experimental design was applied according to the random complete block design in a split arrangement (Split Plots in RCBD). In on hand, the results showed a significant differences between the varieties. The local variety significantly gave highest plant length, leaf area, pods number, seeds number pod-1 and grain yield and which were

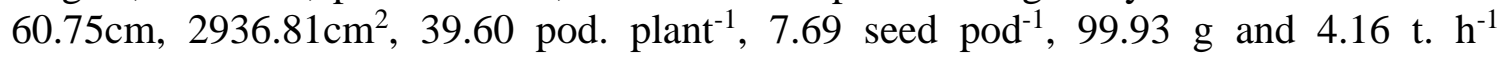
respectively. While the varieties Baton Boa gave highest weight of 100 seeds and gave $37.58 \mathrm{~g}$. In other hand, as compare to the control, the addition of potassium up to $129 \mathrm{~kg}$. $\mathrm{h}^{-1}$ lead to significant increase in plant length, leaf area, pods plant ${ }^{-1}$, seeds number pod-1 and grain yield plant-1 and total grain yield which were $53.33 \mathrm{~cm}, 3455.91 \mathrm{~cm}^{2}, 51.61$ pod. plant ${ }^{-1}, 8.76$ seed. pod $^{-1}, 125.93 \mathrm{~g}$. and $5.25 \mathrm{~T}^{-\mathrm{h}^{-1}}$ respectively. Whereas, the control treatment (K0) gave the highest weight of 100 seeds $(45.11 \mathrm{~g})$. The Interaction between varieties and potassium had a significant effect on almost growth and yield characteristics.
\end{abstract}

Keywords: Cowpea, Varieties, Potassium fertilizer.

\section{Introduction}

Cowpea Vigna sinensis L. is one of the most important legume crops. It is grow vigorously at a hot weather in Africa. Thereafter, it is spread from Africa to Asia and other areas (Khan et al., 2010; Agbogidi \& Egho, 2012). Cowpea is one of the most important legumes plants, it is consider a cheapest plant protein sources in the world. The protein content of cowpea seeds range between $22-33 \%$ while, the carbohydrates range (56.53-57.36)\%, in

addition cowpea used to improve sustain soil fertility through high ability to fixed nitrogen in the soil. The total cultivated area of legumes in Iraq reached to 54.000 dounams in 2013. While, the cultivated area of cowpea crop reached to 47.750 dounams with a total productivity of 74.500 thousand tons 
(Ministry of Planning, Central Statistical Organization Iraq, 2013). Potassium is a major nutrient necessary for field crops production, it comes in third degree after nitrogen and phosphorus. Its plays a significant role in improving quantity and quality of agricultural production (IPI, 2000), Potassium plays a remarkable role in transpiration, stomatal opening and closing and osmoregulation (Cakmak, 2005). It is important to study the performance of cowpea varieties in order to support efforts that caused on developed high quality traits and economic returns (IPI, 2001). The produce of high-yield genotypes alone is not sufficient to improve cowpea productivity because production capacity and genotype are based on physiological processes that are governed by genetic factors and environmental conditions, thus adapting and optimizing the derived genetic structures depends on genetic differences, environmental, climatic and soil conditions (Kamdi; 2001; Lesly, 2005; Aremu et al., 2007). The cowpea crop, did not receive the attention of researchers, especially in the southern region in addition there is rare study on this crop. Therefore this study was conducted to determine the suitable varieties for environmental conditions in the southern region in terms of quantitative and qualitative characteristics as well as determine the best level of potassium fertilizer which gives the highest yield and the best quality of cowpea.

\section{Materials \& Methods}

A field experiment was conducted in $\mathrm{Al}$ Salam area, Maysan province during the autumn growing season 2018. The experiment included two factors: The first factor is three varieties of cowpea, local (control), Patton Boa (the origin is Holland) and ATT A (the origin is USA), which they were symbolized by $\mathrm{V} 1, \mathrm{~V} 2$ and $\mathrm{V} 3$ respectively. The second factor is four levels of potassium in form of potassium sulphate $0,43,86$ and $129 \mathrm{~kg} . \mathrm{h}^{-1}$, which they were symbolized by $\mathrm{K} 0, \mathrm{~K} 1, \mathrm{~K} 2$ and K3 respectively. The treatments replicated three time in random complete block design with split plot design. Potassium were main plots, while the varieties cowpea were sub-plots. Each sub-plot contain 5 rows of $4 \mathrm{~m}$ long and $60 \mathrm{~cm}$ distance between the rows. Soil was prepared by two orthogonal tillage and then the soil was levelled. Nitrogen fertilizer was added to the soil in form of urea $(40 \% \mathrm{~N})$ at $80 \mathrm{~kg} \mathrm{~h}^{-1}$. Phosphate fertilizer was added to the soil in form of triple superphosphate $(21 \% \mathrm{P})$ at $80 \mathrm{~kg} . \mathrm{h}^{-1}$ (Ali, 2012). While, Potassium sulphate was added to the experimental units at three equal timing, the first one before planting, the second one after four weeks of planting and the third one at flowering stage. Random five samples were taken from the field to determine some physical and chemical properties, (shown in Table 1).

Table (1): Some physical and chemical traits of the soil before sowing

\begin{tabular}{cc}
\hline Adjective & the value \\
Sand & $350 \mathrm{~g} \mathrm{~kg}^{-1}$ \\
\hline Silt & $230 \mathrm{~g} \mathrm{~kg}^{-1}$ \\
\hline Clay & $420 \mathrm{~g} \mathrm{~kg}^{-1}$ \\
\hline E.C & $4.9 \mathrm{dsm}^{-1}$ \\
\hline pH & 7.16 \\
\hline Organic matter & $3.0 \mathrm{~g} \mathrm{~kg}^{-1}$ \\
\hline Total nitrogen & $45 \mathrm{mg} \mathrm{kg}^{-1}$ \\
\hline
\end{tabular}




\begin{tabular}{cc}
\hline Available phosphorus & $45.9 \mathrm{mg} \mathrm{kg}^{-1}$ \\
\hline Available Potassium & $60 \mathrm{mg} \mathrm{kg}^{-1}$ \\
\hline
\end{tabular}

Some growth and yield traits were measured, plant height leaf area were determined by the average of 10 plants harvesting from the centre of each plot at the beginning of flowering stage except total leaf area of plant were determined at $50 \%$ using leaf area meter (CI-202 Portable Laser). At maturity stage, the average of pods number plan. $\mathrm{t}^{-1}$, seed number pod-1, weight of 100 seed and grain yield plant-1 were measured from 10 plants harvesting from the central rows of each plot. Grain yield have been measured from the grain yield of the all the plants grown in middle lines. Data were analyzed by using SPSS program. The experimental design was applied according to the random complete block design in a split arrangement (Split Plots in RCBD) The means of traits were tested by using least significant differences (L.S.D.) at probability level 0.05 (Al-Rawai \& Khalaf Allah,1980).

\section{Results \& Discussion}

\section{Plant height (cm)}

The results of Tables (2 and 9) showed that, there is a significant differences between the varieties, potassium fertilizer levels and their interaction. The local variety (V1) produced highest average of plant height of $60.75 \mathrm{~cm}$, while the variety Natun Boa (V3) gave the lowest average of $36.58 \mathrm{~cm}$. This differences in plant height may be because the differences between varieties in response to the surrounding environmental conditions due to varying of their genetic capacity and extent their interaction with environmental conditions. (Al-Othman \& Ibrahim, 2009). This result is consistent with Abayomi \& Abidoye (2009), Al-Tahfi et al. (2014). The results of table (2) indicated that potassium fertilizer level $\mathrm{k} 3$ gave the highest rate of plant height of $53.33 \mathrm{~cm}$, While $\mathrm{k} 0$ gave the lowest rate of plant height of $39.78 \mathrm{~cm}$. This results indicated that there was a clear response to potassium fertilization, may be this attributed to the low of available potassium in soil (see table 1) and to the importance of potassium to the plants throw their attributes in process of cells wall division and expansion as well as the fact that potassium is the basis of physiological functions in plant and metabolic processes. This finding is consistent with the findings of Zeda (2011) which found that potassium levels had a significant effect on plant height of cowpea. It is also noted (Table 2) that the Verity V1 under the treatment of potassium $\mathrm{K} 3$ produced V1K3 the highest rate of plant length of $72.67 \mathrm{~cm}$, while the Verity V1 under the treatment of potassium K0 produced the lowest rate of plant height of $35.00 \mathrm{~cm}$.

Table (2): Response of cowpea varieties to potassium fertilizer levels and their interactions in (cm). plant length.

\begin{tabular}{ccccc}
\hline Potassium levels & \multicolumn{3}{c}{ Varieties } & \multirow{2}{*}{ means (K) } \\
\cline { 2 - 4 } & $\mathrm{V} 1$ & $\mathrm{~V} 2$ & $\mathrm{~V} 3$ & \\
\hline K0 & 47.33 & 37.00 & 35.00 & 39.78 \\
\hline K1 & 55.00 & 41.00 & 36.67 & 44.22 \\
\hline K2 & 68.00 & 39.33 & 36.30 & 47.88 \\
\hline K3 & 72.67 & 49.00 & 38.33 & 53.33 \\
\hline means (V) & 60.75 & 41.58 & 36.58 & \\
\hline
\end{tabular}


L.S.D 0.05 for Potassium=1.90, L.S.D 0.05 for varieties $=1.49$, L.S.D 0.05 for interaction=2.99.

\section{leaf area $\mathrm{cm}^{2}$}

The results of tables ( 3 and 9) indicated that there is a significant differences between the varieties, potassium fertilizer levels and their interaction in leaf area. The local variety (V1) gave the highest mean of leaf area of 2936 $\mathrm{cm} 2$ compared to $\mathrm{V} 3$ which gave the lowest average of $2511 \mathrm{~cm}^{2}$. The reason for the superiority of the local variety may be due to its superiority in the length of the plant and the number of leaves per plant which is reflected positively in increase leaf area. This finding is in agreement with Hassan et al. (2015) which indicated that the varieties of cowpea differ significantly in the leaf area. The results of table (3) indicated that the level of potassium fertilizer level $\mathrm{k} 3$ gave the highest average of the leaf area reached to $3455 \mathrm{~cm} 2$ compared to the control $\mathrm{k} 0$ which gave the lowest average of leaf area of 2058 $\mathrm{cm}^{2}$. The addition of potassium lead to increased leaf area because of the role of potassium in increasing the number and leaves of the plant and activation of the enzymatic systems, which ultimately increases the growth characteristics, including the leaf area. The results of table (3) revealed that the interaction of verities and potassium levels have significant effect on leaf area. The verity V1 under potassium K3 highest average of the leaf area $3884 \mathrm{~cm}^{2}$, while the verity of $\mathrm{V} 3$ under $\mathrm{K} 0$ treatment produced less average of leaf area $1899 \mathrm{~cm}^{2}$, this is due to the effect of single factors.

Table (3): Response of cowpea varieties to potassium fertilizer levels and their interaction in leaf area $\left(\mathrm{cm}^{2}\right)$.

\begin{tabular}{ccccc}
\hline Potassium levels & \multicolumn{3}{c}{ Varieties } & \multirow{2}{*}{ means (K) } \\
\cline { 2 - 4 } & V1 & V2 & V3 & \\
\hline K0 & 2197.90 & 2076.39 & 1899.77 & 2058.02 \\
\hline K1 & 2525.35 & 2430.78 & 2289.58 & 2415.23 \\
\hline K2 & 3139.47 & 2954.61 & 2757.19 & 2950.42 \\
\hline K3 & 3884.52 & 3385.24 & 3097.98 & 3455.91 \\
\hline means (V) & 2936.81 & 2711.76 & 2511.13 & \\
\hline
\end{tabular}

L.S.D 0.05 for Potassium=66.68, L.S.D 0.05 for varieties $=46.77$, L.S.D 0.05 for interaction=93.54.

\section{Pods number per plant}

The results of tables (4 and 9) showed that the varieties, potassium levels and their interaction have significant affected pods number plant $^{-1}$. The local variety $\mathrm{V} 1$ gave the highest rate of pods number plant $^{-1}$ of 39.60 . Whereas the verity V3 produced the lowest average of pods number .plant ${ }^{-1}$ of 31.62 . This may be due to their deferent in genetic ability to exploit the surrounding environmental conditions. and use them in photosynthesis, which helped to increase the transfer ofprocessed of food from source to sink which lead to increase the proportion of flowers and thus led to increase the number of pods plant. This finding is consistent with Khan et al. (2010), Hassan et al. (2015) and Rajab \& Khader 2017 found that cowpea varieties significantly differed in pods number .plant ${ }^{-1}$. The results of table (3) showed that the addition of potassium fertilizer lead to increased pods number. plant ${ }^{-1}$. The potassium level of $\mathrm{K} 3$ gave the highest pods 
number.plant ${ }^{-1}$ of 51.22. While the control average of pods number .plant $^{-1}$ reached to 21.44. This trained of response maybe due to the role of potassium in activating the effectiveness of some special hormones responsible on increasing flowering, and then pod numbers in plant, in addition to the positive role of potassium in increasing the efficiency of carbonization and regulating the transfer the products of photosynthesis to the potassium level (K0) gave the lowest new sites at reproductive stage. These results were consist with Zedan (2011). For the interaction, the results of table (3) revealed that, the local cultivars V1 under potassium level $\mathrm{K} 3$ produced the highest pods number. plant $^{-1}$ of 55.73 . Whereas, the verity V3 under potassium level of V0 has the lowest pods number plant ${ }^{-1}$ of 16.00 . This response is due to the effect of single factors.

Table (4): Response of cowpea varieties to potassium fertilizer levels and their interaction on pods number plant $^{-1}$.

\begin{tabular}{ccccc}
\hline \multirow{2}{*}{ Potassium levels } & \multicolumn{3}{c}{ Varieties } & \multirow{2}{*}{ means (K) } \\
\cline { 2 - 4 } & $\mathrm{V} 1$ & $\mathrm{~V} 2$ & $\mathrm{~V} 3$ & \\
\hline $\mathrm{K} 0$ & 25.73 & 22.60 & 16.00 & 21.44 \\
\hline $\mathrm{K} 1$ & 34.33 & 30.40 & 26.60 & 30.44 \\
\hline $\mathrm{K} 2$ & 42.60 & 40.33 & 36.33 & 39.76 \\
\hline $\mathrm{K} 3$ & 55.73 & 50.40 & 47.53 & 51.22 \\
\hline means $(\mathrm{V})$ & 39.60 & 35.93 & 31.62 & \\
\hline
\end{tabular}

L.S.D 0.05 for Potassium=0.89, L.S.D 0.05 for varieties $=0.71$, L.S.D 0.05 for interaction=1.42.

\section{Seeds number in a pod (seed.pod $\left.{ }^{-1}\right)$}

The results of tables (5 and 9) exhibited that, there are significant effect for varieties, potassium fertilizer levels and their interaction in seeds $\cdot$ pod $^{-1}$. The local variety (V1) gave the highest number of seeds pod $^{-1}$ of 7.69, while the Baton Boa (V3) recorded the lowest seeds. pod $^{-1}$ reached to 6.85 seeds. $\operatorname{pod}^{-1}$. These differences may be due to the high genetic susceptibility of the local variety to exploit the surrounding environmental conditions and use it in the process of photosynthesis, which helped to increase the growth and increase flowers, pollination and fertilization by regulating the growth and variety of plant hormones in the reproductive stage so thus increase the number of seeds $\operatorname{pod}^{-1}$. This result was consistent with the findings of Hassan et al. (2015), Kahraman, (2017) and Rajab and Khader, (2017). They found that cowpea varieties differed in the number of seeds in pods. The results of table (5) showed that the level of potassium k3 gave the highest seeds.pod ${ }^{-1}$ of 8.76 , while the control treatment of potassium $(\mathrm{k} 0)$ gave the lowest average of seeds pod $^{-1}$ of 6.01 .

Potassium contributed in regulation of transfer metabolites to the new evolutionary sites in the reproductive stage of plant, so lead to increase the fertility and nodes number. This result is consistent with the results of some researchers who they found that the addition of potassium resulted in significant increase in the number of seeds per cornea in 
cowpea crop (Khan et al., 2010; Mansouri \&

Shokoohfar, 2015).

Table (5): Response of cowpea varieties to potassium fertilizer levels and their interaction in seeds number. $\operatorname{pod}^{-1}$.

\begin{tabular}{ccccc}
\hline \multirow{2}{*}{ Potassium levels } & \multicolumn{3}{c}{ Varieties } & means (K) \\
\cline { 2 - 4 } & V1 & V2 & V3 & \\
\hline K0 & 6.40 & 6.03 & 5.60 & 6.01 \\
\hline K1 & 7.27 & 6.93 & 6.50 & 6.90 \\
\hline K2 & 7.60 & 7.70 & 7.37 & 7.56 \\
\hline K3 & 9.50 & 8.83 & 7.93 & 8.76 \\
\hline means (V) & 7.69 & 7.38 & 6.85 & \\
\hline
\end{tabular}

L.S.D 0.05 for Potassium=0.30, L.S.D 0.05 for varieties $=0.71$, L.S.D ${ }_{0.05}$ for interaction=0.43

For the interaction. The variety of V1 under K3 fertilizer level gave the highest seeds pod $^{-}$ ${ }^{1}$ of 9.50 , whereas the variety $\mathrm{V} 3$ under nonpotassium fertilizer $(\mathrm{V} 3 \times \mathrm{K} 0)$ gave the lowest seeds. pod $^{-1}$ of 5.60 .

\section{0 seeds weight $(\mathrm{g})$}

The results of tables (6 and 9) displayed that there are significant differences between varieties, potassium levels and their interaction in weight of 100 seeds, The Baton Boa V3 gave the highest rate in the weight of 100 seeds of $37.58 \mathrm{~g}$, while the local variety V1 produced the lowest trait rate weight of 100 seeds of $33.75 \mathrm{~g}$. local variety gave highest seed number. pod $^{-1}$ (Table 4 ) this lead to increasing competition between seeds within the pod on nutrients in development and seed falling stage within the pod, which reflect negatively on weight of 100 seeds. This was confirmed by the significant negative correlation between seed number. pod $^{-1}$ and weight of 100 . The result was consistent with Kahraman (2017), who reported a significant difference between cowpea genotypes in the weight of 100 seeds. The results of Table (6) showed significant effect for potassium fertilizer level on weight of 100 seeds. The control treatment $(\mathrm{K} 0)$ gave highest seed weight of 100 seeds of $45.11 \mathrm{~g}$ compared with the level K3 which gave the lowest rate of $28.00 \mathrm{~g}$. The addition of potassium fertilizer lead to increased seed number. pod $^{-1}$ (see Table 4) so this lead to increase the compotation between the seeds on the photosynthesis production which reflect negatively on weigh of 100 seed (Table 5). This results was not consistent with Seran (2010) and JafarUllah et al. (2012) who they found a significant increase in the weight of 100 seeds when potassium was added. For the interaction, the results of table (5) revealed that, the variety $\mathrm{V} 3$ under potassium level $\mathrm{K} 0$ gave the highest average of weight of 100 seed of 46.33, while the interaction of V1 with $\mathrm{K} 3$ gave the lowest average reached to $26.33 \mathrm{~g}$.

\section{Yield of individual plant (g plant $\left.{ }^{-1}\right)$}

The results of table (7 and 9) revealed that there is significant effect for varieties and potassium fertilizer levels, whereas there is significant effect for their interaction. The variety V1 produced the higher yield reached to $99.93 \mathrm{~g}$.plant ${ }^{-1}$ while the variety V3 produced the lowest yield reached to $79.42 \mathrm{~g}$. plant $^{-1}$. The reason is that, the variety $\mathrm{V} 3$ gave 
Table (6): Response of cowpea varieties to potassium fertilizer levels and their Interaction on weight of $100(\mathrm{~g})$.

\begin{tabular}{ccccc}
\hline \multirow{2}{*}{ Potassium levels } & \multicolumn{3}{c}{ Varieties } & means (K) \\
\cline { 2 - 4 } & V1 & V2 & V3 & \\
\hline K0 & 43.67 & 45.33 & 46.33 & 45.11 \\
\hline K1 & 34.33 & 35.67 & 39.67 & 36.56 \\
\hline K2 & 30.67 & 36.33 & 34.67 & 33.89 \\
\hline K3 & 26.33 & 28.00 & 29.67 & 28.00 \\
\hline means (V) & 33.75 & 36.33 & 37.58 & \\
\hline
\end{tabular}

L.S.D 0.05 for Potassium=2.03, L.S.D 0.05 for varieties =1.44, L.S.D 0.05 for interaction=2.87

the highest seeds. $\operatorname{pod}^{-1}$ and seeds number.plant ${ }^{-1}$ which reflect positively on plant yield (Tables 4 and 5). This results was in agreement with Kahraman (2017). The results of table (7) showed that the addition of potassium lead to increased yield of individual plant. The potassium level of V3 gave the highest yield of plant (125.93 g plant $\left.^{-1}\right)$. While the control level produced the lowest average reached to $59.27 \mathrm{~g} \mathrm{plant}^{-1}$.The increased of potassium fertilizer lead to increased pod number plant ${ }^{-1}$ and seeds number pod $^{-1}$ (Tables 4 and 5) which reflect positively in increased the yield of plant. In addition, potassium lead to increased plant yield throw improved translocation of photosynthesis product from leaves to sink. Moreover, Potassium improve enzyme activity specially the enzyme which play role in energy transferred and production of ATP complex.

Table (7): Response of cowpea varieties to potassium fertilizer levels and their interaction in yield of individual plant $\left(\mathrm{g} \mathrm{plant}^{-1}\right)$

\begin{tabular}{ccccc}
\hline V/k & \multicolumn{3}{c}{ Varieties } & means (K) \\
\cline { 2 - 4 } & $\mathrm{V} 1$ & $\mathrm{~V} 2$ & $\mathrm{~V} 3$ & \\
\hline $\mathrm{K} 0$ & 73.04 & 62.66 & 42.12 & 59.27 \\
\hline $\mathrm{K} 1$ & 86.61 & 75.92 & 69.56 & 77.36 \\
\hline $\mathrm{K} 2$ & 99.95 & 113.43 & 93.36 & 102.25 \\
\hline $\mathrm{K} 3$ & 140.13 & 125.03 & 112.64 & 125.93 \\
\hline means $(\mathrm{V})$ & 99.93 & 94.26 & 79.42 & \\
\hline
\end{tabular}

L.S.D 0.05 for Potassium=4.29, L.S.D 0.05 for varieties $=5.97$, L.S.D 0.05 for interaction=n.s

\section{Total grain yield $\left(\mathbf{t} . \mathbf{h}^{-1}\right)$}

The results of tables ( 8 and 9) presented that, there is significant effect for varieties and potassium fertilizer levels. While the results revealed that there is no significant effect for their interaction. The variety $\mathrm{V} 1$ gave the highest total grain yield reached to $4.16 \mathrm{t}$. $\mathrm{h}^{-1}$, whereas the variety V3 gave the lowest average of $3.31 \mathrm{t} . \mathrm{h}^{-1}$ (Table 8 ). The reason is because of the locale variety V1 produced 
Al-Furtuse et al ./ Basrah J. Agric. Sci., 32(Spec. Issue 2): 25-34, 2019

highest pod number. plant ${ }^{-1}$, seeds number pod-1 and the yield of individual plant (Tables 4, 5 and 7). The results indicated that the increased potassium fertilization lead to increased total grain yield. The level V3 gave the highest grain yield of $5.25 \mathrm{t} . \mathrm{h}^{-1}$, whereas the control level (V0) gave the lowest grain yield of 2.47 t. $\mathrm{h}^{-1}$. potassium fertilizer lead to improve pod number . plant $^{-1}$, seeds number . pod $^{-1}$ and the grain yield of individual plant (Tables 4, 5 and 7), so the total grain yield have been significantly increased by applied $\mathrm{K} 3$ by $12.50 \%$ as compared to K0.

Table (8): Response of cowpea varieties to potassium fertilizer levels and their interaction in total yield (t. $\left.h^{-1}\right)$.

\begin{tabular}{ccccc}
\hline Potassium levels & \multicolumn{3}{c}{ Varieties } & \multirow{2}{*}{ means (K) } \\
\cline { 2 - 4 } & V1 & V2 & V3 & \\
\hline K0 & 3.04 & 2.61 & 1.75 & 2.47 \\
\hline K1 & 3.61 & 3.16 & 2.90 & 3.22 \\
\hline K2 & 4.16 & 4.73 & 3.89 & 4.26 \\
\hline K3 & 5.84 & 5.21 & 4.69 & 5.25 \\
\hline means (V) & 4.16 & 3.93 & 3.31 & \\
\hline
\end{tabular}

L.S.D 0.05 for Potassium $=0.18$, L.S.D 0.05 for varieties $=0.25$, L.S.D 0.05 for interaction $=$ n.s

Table (9): Analysis of variance represented by mean square of traits measured.

\begin{tabular}{|c|c|c|c|c|c|c|c|c|}
\hline $\begin{array}{c}\text { Sources of } \\
\text { variation }\end{array}$ & df & Plant height & leaf area $\mathrm{cm}^{2}$ & $\begin{array}{c}\text { Pods } \\
\text { number } \\
\text { per plant }\end{array}$ & $\begin{array}{c}\text { Seeds } \\
\text { number in a } \\
\text { pod } \\
\left.\text { (seed.pod }^{-1}\right)\end{array}$ & $\begin{array}{c}100 \text { seeds } \\
\text { weight } \\
\text { (g) }\end{array}$ & $\begin{array}{c}\text { Yield of } \\
\text { individual } \\
\text { plant }(\mathrm{g} \\
\text { plant }^{-1}\end{array}$ & $\begin{array}{c}\text { Total } \\
\text { grain } \\
\text { yield (t. } \\
\text { ha-1) }^{-1}\end{array}$ \\
\hline Blook & 2 & 48.08 & 255009.72 & 42.76 & 8.42 & 29.36 & 3942.60 & 6.84 \\
\hline K & 3 & $296.44^{* *}$ & $3377296.39^{* *}$ & $\begin{array}{c}1464.68^{*} \\
*\end{array}$ & $12.02^{* *}$ & $455.19^{* *}$ & $7617.61^{* *}$ & $13.22^{* *}$ \\
\hline $\mathrm{E}(\mathrm{k})$ & 6 & $2.70^{\text {n.s }}$ & $3340.98^{* *}$ & $0.60^{\text {n.s }}$ & $0.07^{\text {n.s }}$ & $3.10^{\text {n.s }}$ & $13.81^{* *}$ & $0.02^{\text {n.s }}$ \\
\hline V & 2 & $1953.75^{* *}$ & $544204.96^{* *}$ & $191.62^{* *}$ & $2.17^{* *}$ & $45.86^{* *}$ & $1346.59^{* *}$ & $2.34^{* *}$ \\
\hline $\mathrm{KxV}$ & 6 & $99.14^{*}$ & $50105.18^{* *}$ & $3.15^{*}$ & $0.23^{*}$ & $5.49^{*}$ & $167.28^{\text {n.s }}$ & $0.29^{\text {n.s }}$ \\
\hline $\mathrm{E}(\mathrm{V})$ & 16 & 2.98 & 2920.33 & 0.68 & 0.06 & 2.75 & 47.53 & 0.08 \\
\hline Total & 35 & & & & & & & \\
\hline
\end{tabular}

n. S., means No significant differences, * :means significant differences were found at $(\mathrm{P}<0.05)$, ** means significant differences were found at $(\mathrm{P}<0.01)$. 


\section{Conclusion}

The local variety significantly defer from other varieties and produced higher grain yield of $5.84 \mathrm{t} \mathrm{ha}^{-1}$, also it is more adaptive for local environment as compared to other varieties. The addition of potassium fertilization lead to increased growth and grain yield, so this revealed the high contribution of potassium in supporting plant growth at deferent growth stages. The high level of potassium gave $5.25 \mathrm{tha}^{-}$ 1 .

\section{Acknowledgements}

I would like to thanks and appreciate Dr. Kareem H. Mohsen, head of department of Field Crops for his advises and supporting during my study. I also wish to thanks Dr. Sundus A. Al-Abdullah for her scientific advices, supporting and help.

\section{References}

Abayomi, Y.A. \& Abidoye, T.O. (2009) Evaluation of cowpea genotypes for soil moisture stress tolerance under screen house conditions. Afr. J. Plant. Sci., 3 (10): 229-237.

Agbogidi, O.M. \& Egho, E.O. (2012) Evaluation of eight varieties of cowpea (Vigna unguiculata L. Walp) in Asabe agro-ecological environment, Delta state, Nigeria. European J. Sustainable Dev., 1(2): 303-314.

Al-Othman, M.K. \& Ibrahim, A. (2009). Effect of planting date and plant density on the productivity of ordinary bean Vicia fabf L. in Deir Ezzor governorate. Damascus J. Agric. Sci., 25(2): 77-93. . (In Arabic).
Al-Rawi, K.M. \& Khalaf Allah, A.A.M. (1980). Design and Analysis of Agricultural Experiments. Min. High. Educ. Sci. Res. Univ. Baghdad: 448pp.

Al-Tahfi， S.A.A.M.; Hussein, L.M.; Kazem, R.K. \& Majbas, A.H. (2014). Effect of bio-fertilizer Anfazyme on growth and yield of two varieties of cowpea. Al -Muthanna J. Agric. Sci., 2(1): 1-13. (In Arabic).

Aremu, C.O.; Ariyo, J. \& Adewale, B.D. (2007). Assessments of selection techniques in genotype environment interaction in cowpea (Vigna unguiculata (L.) Walp). Afr. J. Agric. Res., 2(8): 352- 355.

Cakmak, I. (2005). The role of potassium in alleviating detrimental effects of a biotic stresses in plants. J. Plant Nutr. Soil Sci., 168: 521-530.

Hassan, H.I.; Badie, S. \& Suhail, M. (2015). Evaluation of some cowpea varieties in terms of growth, production quantity and quality. Tishreen Univ. J. Res. Sci. Stud.- Bio. Sci., Ser., 37(3): 471-481. (In Arabic).

I.P.I. (International Potassium Institute). (2001). Potassium in plant production. Basel, Switzerland: 44pp.

JafarUllah, M.D.; Fattah, Q.A. \& Hossan, F. (2012). Effect of potassium napthenate on yield attributing characters and seed yield of cowpea cv. Bari falon-1 (Vigna unguiculata (L.) Walp.) grown under early Rabi season. Bangladesh J. Bot., 36(1): 29-32.

Kahraman, A. (2017). Effect of humic acid doses on yield and quality parameters of cowpea (Vigna unguiculata (L.) 
Walp) cultivars. Agri. Res. Comm. Cen., 40(1): 155-159.

Kamdi, R. (2001). Relative stability, performance, and superiority of crop genotypes across environment. J. Agric. Biol. Environ. Stat., 6:449-460.

Khan, A.; Bari, A.S.; Khan, N.H.; Zada. I. (2010) Performance of cowpea genotypes at higher altitude of NWFP. Pak. J. Bot., 42(40): 2291-2296.

Lesly, W.D. (2005). Characterization and evaluation of cowpea (Vigna unguiculata L. Walp). Germplasm M. Sc. Thesis, Univ. Agric. Sci., Dharwad: 94pp.
Mansouri, S. \& Shokoohfar, A. (2015). Effect of potassium fertilizer and irrigation intervals levels on yield and yield components of cowpea (Vigna unguiculata L.) in ahvaz condition. Indian J. Fund. Appl. Life Sci., 5(1): 26-32.

Zedan, G.J. (2011). Effect of potassium fertilizer and foliar application of nutrient Solution (Growth) on the growth and yield of cowpea (Vigna sinensis L.) planted in a gypsiferous soil. J. Tikrit Univ. Agric. Sci., 11(4): $1-10$. 